\title{
PROFESSIONAL ORGANIZATIONS VERSUS INTERNATIONAL MEDICAL GRADUATES AND FOREIGN-TRAINED ENGINEERS \\ by
}

Saad El Hakmi, BA, Seneca College, 2016

\author{
A Major Research Paper \\ presented to Ryerson University
}

in partial fulfillment of the requirements for the degree of

\author{
Master of Arts \\ in the program of \\ Immigrant and Settlement Studies
}

Toronto, Ontario, Canada, 2017

(C) Saad El Hakmi 2017 


\section{AUTHOR'S DECLARATION}

AUTHOR'S DECLARATION FOR ELECTRONIC SUBMISSION OF A MAJOR RESEARCH PAPER (MRP)

I hereby declare that I am the sole author of this Major Research Paper. This is a true copy of the MRP, including any required final revisions.

I authorize Ryerson University to lend this MRP to other institutions or individuals for the purpose of scholarly research

I further authorize Ryerson University to reproduce this MRP by photocopying or by other means, in total or in part, at the request of other institutions or individuals for the purpose of scholarly research.

I understand that my MRP may be made electronically available to the public. 


\title{
PROFESSIONAL ORGANIZATIONS VERSUS INTERNATIONAL MEDICAL GRADUATES AND FOREIGN-TRAINED ENGINEERS
}

\author{
Saad El Hakmi \\ Masters of Arts, 2017 \\ Immigration and Settlement Studies \\ Ryerson University
}

\begin{abstract}
This paper explores the exclusionary practices in Canada conducted by professional organizations towards international medical graduates (IMG's) and foreign-trained engineers through a literature review and critical discourse analysis of the certification process. The political economy approach explains the constant need of Canada to bring highly skilled immigrants but there is a discrepancy between their selection and the labour market outcome. The discourse analysis reveals that professional organizations use policies and regulations (that protect the White mainstream Canadian values) as a legitimate tool to impose tough requirements that devaluate IMG's and foreign-trained engineers' credentials/work experiences and prevent them from practicing their professions in Canada.
\end{abstract}

\section{Key words:}

Highly skilled immigrants, political economy, social capital, international medical graduates, foreign-trained engineers, professional organizations, devaluation of academic and professional skills 


\section{Acknowledgements}

I would like to express my profound gratitude and appreciation to many individuals that supported me through the process of writing this thesis.

First, thank you to Dr. Cheryl Teelucksingh for being a wonderful professor, supervisor and mentor. You have been a valuable source of positive energy, inspiration and motivation through the whole academic year. It has been a pleasure being your student and working with you as graduate assistant.

Second, thank you Dr. Harald Bauder for being my second reader and for your tremendous expertise and contribution to the literature of my thesis topic.

Third, I would like to give special thanks my friend and brother Souhail for the long journey and the wonderful path that we went through. You have been a model to me and I would not have made it without your encouragement and support.

Lastly, thank you my fellow classmates specifically the GLC crew for the moments that we lived together. Your support was incredible and you have all demonstrated that you are more than classmates. 


\section{Table of Contents}

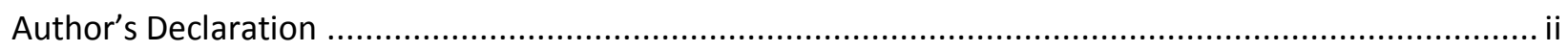

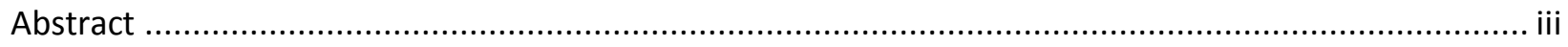

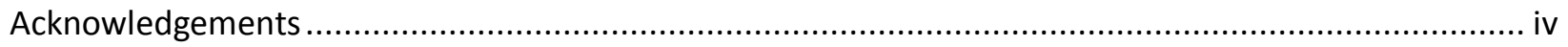

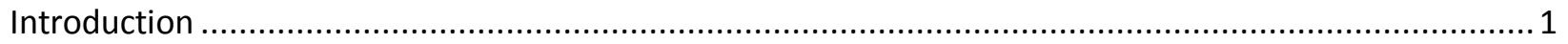

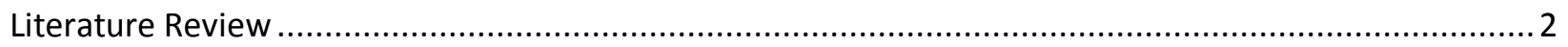

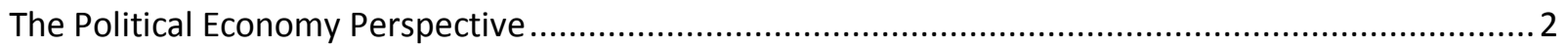

Skills Devaluation and Non-Recognition of Foreign Trained Professionals' Credentials ...................... 4

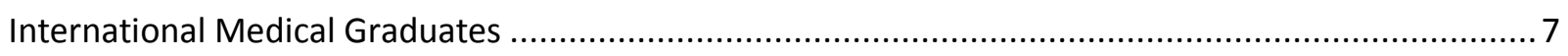

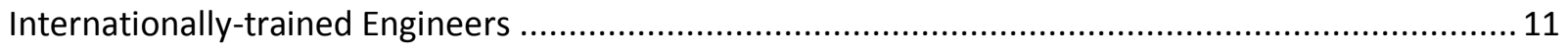

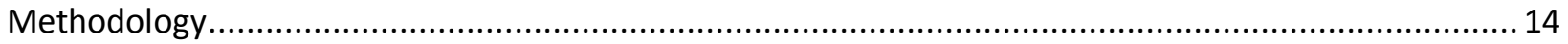

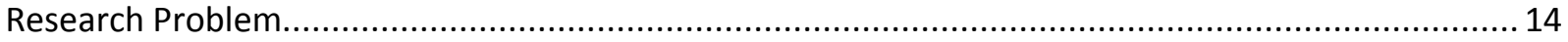

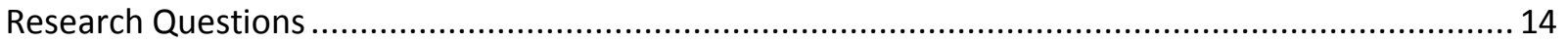

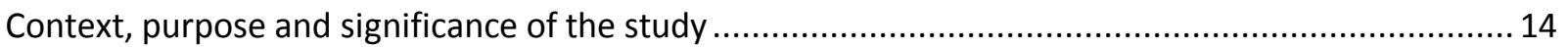

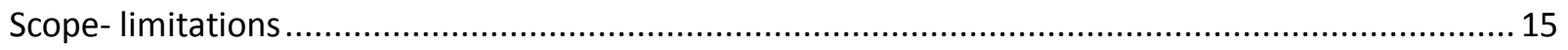

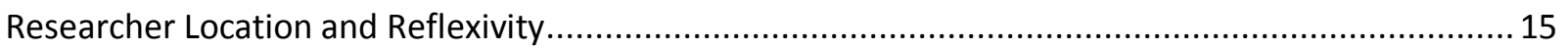

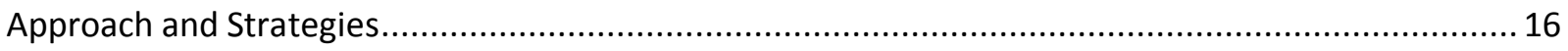

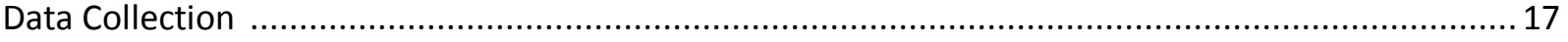

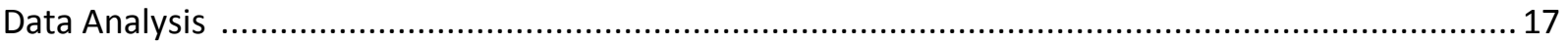

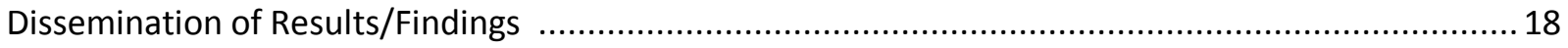

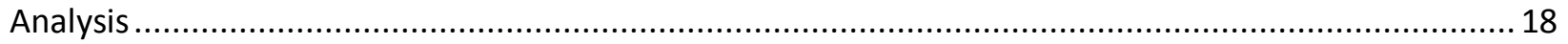

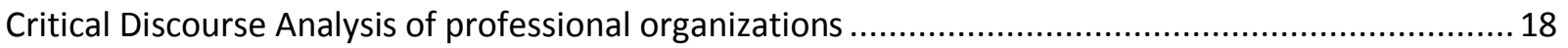

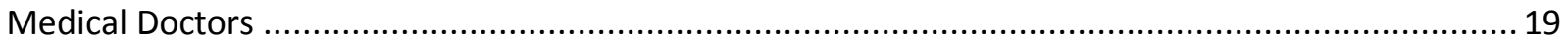

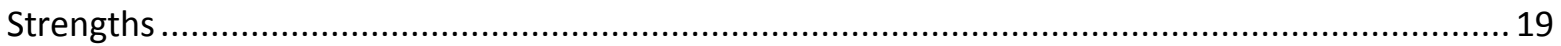

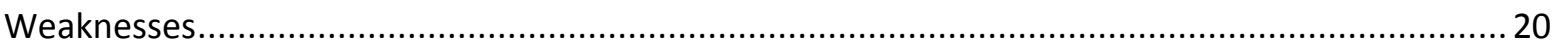

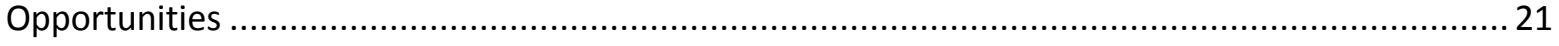

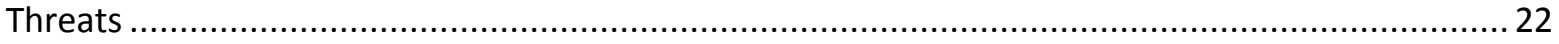

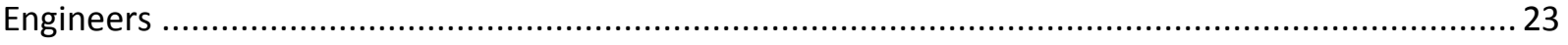

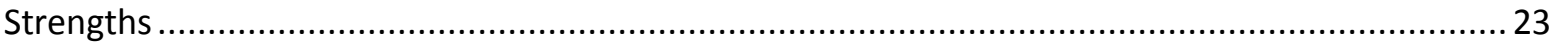

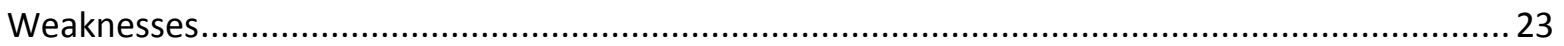

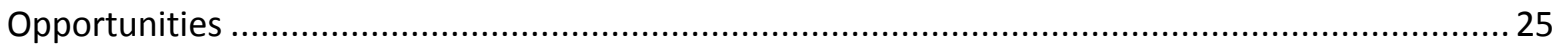

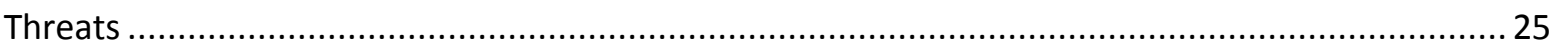

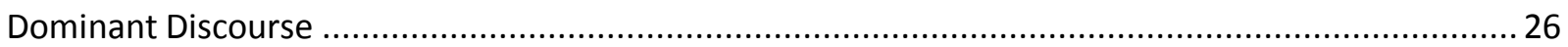




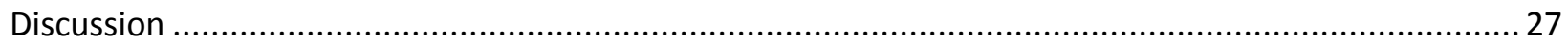

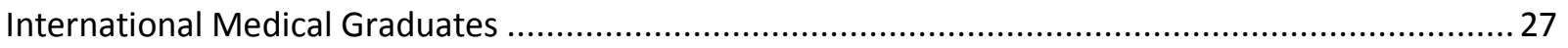

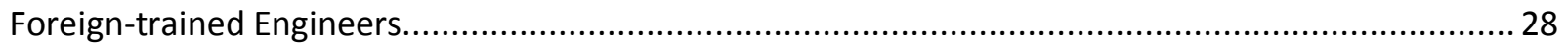

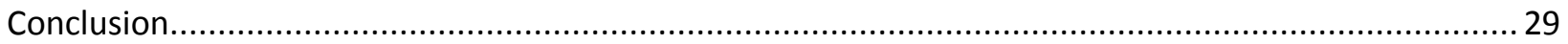

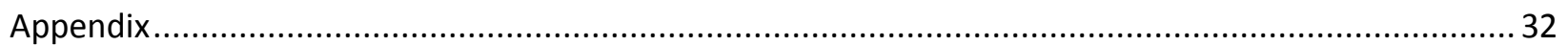

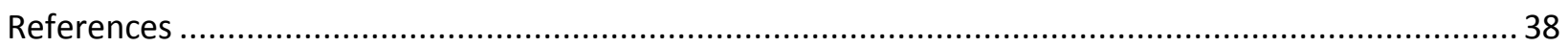




\section{Introduction}

Professional organizations such as Canadian Medical Association and Engineers Canada play a significant role in excluding highly skilled foreign doctors and engineers from higher positions in the Canadian labour market. Existing literature such as Bauder (2003), Girard and Bauder (2007), Foster (2008) and Shibao (2009) underlines the non-recognition of foreign education and work experiences of highly skilled immigrants but it fails to explain the discrepancy between immigration selection policy and the specific practices of professional organizations towards them. From the political economy perspective, global capitalism and neoliberalism push Canadian immigration actors, such as the Canadian government, to seek progressively highly skilled professionals such as medical doctors and engineers to fulfill local economic needs without recognizing foreign trained professionals' education and work experience. The purpose of this research is to identify the gaps in existing research about the functioning of such organizations and its impact on highly skilled immigrants; it addresses the following questions: Why do professional organizations such as the Canadian Medical Association and the Engineers Canada create barriers for highly skilled foreign doctors and engineers to practice their own profession in Canada? How do these practices exclude? This research draws on a literature review and critical discourse analysis of the certification process for the professions of medicine and engineering in Canada. Data for the critical discourse analysis has been collected from federal and provincial professional organizations' websites then analyzed in order to reveal both the systemic discourse and practices that these organizations use to prevent highly skilled foreign doctors and engineers from practicing their professions in Canada. 


\section{Literature Review}

The literature review consists of four main sections. The first section examines the political economy perspective and its relationship to foreign trained professionals. The second section briefly reviews the literature on the non-recognition of foreign- trained professionals' education and work experience. The third section explores the literature about the process of medical licensing in Canada, including the licensing process as well as the barriers that international medical graduates (IMG's) experience during that process. The fourth section focuses on the licensing of international engineers and their experiences in the labour market.

\section{The Political Economy Perspective}

The political economy perspective is a framework that examines global and local inequalities and imbalances of power, disadvantaging immigrants. The political economy builds from capitalism that places capitalist entities as the powerful and workers as the exploited (Callon, 2016). Transnational and multinational companies have undermined the states and took control of the market under capitalism (Callon, 2016). Global capitalism and neoliberalism became the new forms of the global economy that controls our social, economic and political world (Callon, 2016). Global capitalism, which became operational between late 1970's and the beginning of 1980's, is a response to global events such as collapse of Communist East, undermining of developed states in the Global South, and the weakening of welfare states in the Capitalist West (Callon, 2016). As a similar process, neoliberalism emerged in late 1980's to early 1990's and represents an ensemble of economic policies, such as reduced taxation, privatization, deregulation, and liberalization of the market in order to adjust the balance of forces towards capital. For instance, neoliberalism puts powerful capitalist class as winners and foreign labour migrants as losers (Callon, 2016). Due to colonialism, capitalism, and 
imperialism, most immigrants from developing countries come with a cultural inferiority complex due to chronic class inequality and sense of static inefficacy (Anton, 2010). The colonizer imposes rules that play in his advantage while the colonized develop a psychoaffective attachment towards his dominant. This attachment maintains the economic and political structure and relationship between the colonizer and the colonized (Coulthard, 2007). Colonized populations undergo a process of internalization of degrading images imposed by the colonizer and they accept it overtime (Coulthard, 2007). They continue to struggle with the same problems once they arrive in the country of destination, where they are socially marked by their ethnicity, race, and national origin (Anton, 2010).

The use of political economy framework in this paper is fundamental because it explains why Canada needs consistently highly skilled professionals such as medical doctors and engineers. Canada is a capitalist and liberal democratic society that lives with the paradox of accepting social inequality and racism while celebrating multiculturalism that claims equal status for all (Anton, 2010). Canada was among those states that under the pressure of global capitalism had to bring foreign cheap labour to protect its own position in the global political economy (Callon, 2016). The recent Canadian immigration trends segmented capitalist labour forces categorizing immigrants by class, gender, nationality, or race in response to the social and economic changes made by global capitalism and neoliberalism. In fact, globalization supports the hierarchy that includes and excludes migrants based on the economic needs (Callon, 2016). Canadian immigration policies reaffirm the global hierarchy of class, gender and race. The Canadian state tends to marginalize its individuals by labeling them as temporary workers or permanent resident that are not the same as citizens (Callon, 2016). Despite their highly qualifications and competencies, medical doctors and engineers are victims of such policies. 


\section{Skills Devaluation and Non-Recognition of Foreign Trained Professionals' Credentials}

Shibao (2009) and Bauder (2003) are two seminal sources that highlight the lack of recognition of foreign credentials on skilled immigrants' professional experience in Canada. According to Shiboa $(2009,38)$, the non- recognition of skilled immigrants' credentials and professional experiences is one of the most relevant settlement issues in Canada. Bauder (2003) highlights that form of devaluation applied by Canadian institutions towards skilled immigrants leading to their underemployment in the Canadian labour market. Foreign credentials and professional work experiences are trivialized and qualified as incompatible with dominant expectations in the Canadian labour market (Shibao, 2009). Bauder $(2003,700)$ draws on Pierre Bourdieu's notion of institutionalized cultural capital as a theoretical framework to illustrate the marginalization of foreign skilled immigrants in the labour market by institutions. Cultural capital represents the value and competence of foreign skilled immigrants based on their credentials. Through the process of immigration, Canada selects its immigrants based on their highly cultural capital. However, most of the Canadian institutions waste that cultural capital by devaluating highly skilled immigrants' credentials and professional experiences, acquired in their countries of origin (Girard \& Bauder, 2007). Therefore, institutionalized cultural capital leads to a reproduction of the existing class structure by giving labour market advantages to individuals with Canadian degrees and diplomas (Bauder, 2003). Girard and Bauder provide convincing reasons of the non-recognition of foreign credentials and they link it to the negative connotations associated with immigrants. They further affirmed that foreign trained professionals such as medical doctors have their credentials devaluated by professional organizations that protect the Canadian standards. However, Girard and Bauder do not explain why the Canadian credential 
norms should be the only standard for assessing foreign credentials. There is also a lack of consideration in the existing literature of the beginning to end process of credentials assessment by the professional organizations. This study responds to the need to do a systematic analysis of how foreign credentials are assessed by the Canadian institutions.

Shibao’s article (2009) “Difference, Deficiency, and Devaluation: Tracing the Roots of Non-Recognition of Foreign Credentials for Immigrant Professionals in Canada" uses a critique of positivism and pluralism to explain how dominant Canadian values influence the perception of foreign immigrants by individuals and institutions while assessing their foreign credentials. Using critical theory and postmodernism to examine the relationship between power and knowledge, Shibao (2009) also argues that the non-recognition of immigrants' credentials is a political act. First, Western misconception of what counts as knowledge and how to evaluate differences leads institutions to see non-Western immigrants as inferior, deficient and noncompatible (Shibao, 2009). Second, according to Shibao, dominant shared values in Canadian society are tied to notions of pluralism and positivism, which encourage tolerance rather than acknowledging diversity and differences (Shibao, 2009). Tolerance toward immigrants is problematic because it strengthens the superiority of mainstream Canadian society over the new comers and labels immigrants as being strangers that are lucky to be accepted in Canada. Immigrants are also socially constructed based on their skin color and, therefore, many immigrants are often perceived by Canadians as: outsiders, non-fluent English speakers, inferior to the norms, and ones who are working in low-skilled jobs (Shibao, 2009). These dominant social constructions reinforce racial, ethnic, and cultural stereotypes, which hinder the successful settlement and integration of immigrants. In response to these social constructions, Shibao advocates for a more inclusive society that validates the differences and gives immigrants equal 
status as "real" Canadians. Although, the critique of positivism and pluralism discusses this phenomenon, there is a need to understand why such values are embedded in the Canadian society.

The Canadian professional organizations control the upper segment of the labour market and exclude skilled immigrants from full participation and inclusion in the labour market, protecting highly qualified positions (Bauder, 2003). Regulated professions require professional certification after the bachelor level, while unregulated professions only need a bachelor degree or diploma (Shibao, 2009). Canadian professional organizations benefit from the support of the government and legislation that inform the professional certification process. In this sense, government policies contribute to the differential's assessment of foreign credentials (Bauder, 2003). This is a challenging situation for newcomers because failing to receive professional certification has a negative impact on their professional future. What seems to be an advantage for Canadian economy turns out to be an economic loss and brain waste of the skilled foreign workers (Bauder 715). Bauder provides insightful and concrete information on Canadian professional organizations and their powerful role in the Canadian labour market. However, Bauder's research does not closely examine the exclusionary practices of such bodies towards highly skilled professionals. Responding to this gap, using a critical discourse analysis, this study analyzes how professional organizations prevent medical doctors and foreign trained engineers from practicing their professions in Canada. Before reviewing literature on International medical graduates, it is imperative to understand the role of political economy in bringing foreign trained talents to Canada. 


\section{International Medical Graduates}

Provincial jurisdiction controls healthcare and licensing process for doctors in Canada. For example, in the province of Ontario, international medical graduates (IMG's) must successfully finish a highly competitive process of evaluation as outlined by the International Medical Graduates of Ontario (Wong \& Lohfeld, 2008). The Medical Council of Canada applies tough standards on the medical profession. For instance, they require foreign-educated doctors to do a two to six years university-based postgraduate medical training and pass a written exam (Bauder, 2003). The postgraduate medical training, also called residency training, is a government-funded program that takes place in universities and colleges to train future physicians and prepare them for the final licensing (Neiterman \& Bourgeault, 2012). International Medical Graduates of Ontario is a self- regulatory professional body that assesses IMG's and evaluates their acceptance into postgraduate training programs that are mandatory to practice their profession (Wong \& Lohfeld, 2012). To practice medicine in Canada, all medical graduates need to pass the Medical Council of Canada Qualifying Examination, which has Part I and Part II. In order to write the Part I, most of IMG's need to pass the Medical Council of Canada Evaluating Examination. In addition, most provinces require IMG's to pass a National Assessment Collaboration (NAC) test, in order to be eligible for postgraduate residency training (Curtis \& Dube, 2015). This process is certainly complicated for international trained doctors, especially for the ones that are older and have been practicing for more than 10 years.

Wong's and Lohfeld's phenomenological study in 2003-2005 explored the experiences and recertification process of twelve international medical graduates in Canada (Wong \& Lohfeld, 2008). The sample of research contained 7 men and 5 women from Asia, Latin 
America, the Caribbean, the Middle East and Eastern Europe. All of the participants had completed their training, residency and were practicing in their countries of origin (Wong \& Lohfeld, 2008). The participants affirmed experiencing barriers to enter the training programs, as well as the three phase process of loss, disorientation and slow adaptation (Wong \& Lohfeld, 2008). Most of the participants agreed that they faced difficulties in gaining acceptance to the medical training program. For instance, they described the process as stressful, highly selective, difficult and ambiguous (Wong \& Lohfeld, 2008). It is important to have a IMGs' feedback on what they experience in Canada but this research did not analyze case by case process of certification.

In 2009, the Minister of Immigration condemned the Canadian shortage of physicians while foreign trained physicians were cleaning hotel rooms due to the control and influence of medical associations on the labour markets (Curtis \& Dube, 2015). Delacourt (2009) affirmed that further to this condemnation, eight professional organizations, except the one responsible for medicine agreed to speed up the process of credential recognition for foreign-trained professionals. Despite the shortage of doctors in Canada, international medical graduates face barriers such as retention and credentialing, recruitment barriers, and complex certification process (Wong \& Lohfeld, 2008). Immigration policies have changed over the past 50 years to facilitate the entry of international medical graduates that are non-White and non-European, while in the past IMG's were predominantly from the UK and Ireland (Neiterman \& Bourgeault, 2012). The point system allowed the selection of IMG's based on the high demand of their occupation in the Canadian labour market (Neiterman \& Bourgeault, 2012). Starting from 2003, provincial governments have increased the number of residency seats, but only 10 percent is available for IMG's. There are very few and limited residency spots for international medical graduates in comparison to the 
increasing number applying for them. Physician specialists are facing tremendous difficulties in finding employment. In fact, in 2013, around $16 \%$ of new specialists did not find work while $31 \%$ of them went for additional training to increase their chances of employment (Curtis \& Dube, 2015). Despite the changes in the Canadian immigration and provincial policies to bring more IMG's, medical professional organizations have the final say on how to practice medicine in Canada.

After their acceptance in the training program, IMG's enter the phase of loss in which they struggled with both their personal and professional identities. In fact, they lost their ability to fulfill familial roles and their personal belonging. They also suffer from professional devaluation (Wong \& Lohfeld, 2008). Wong and Lohfeld (2008) affirmed: One of the participants expresses his frustration with the licensing process: "You felt dehumanized, in a sense, as if you had lost something that you had already achieved- that [your profession] had been taken away from you. You had to sort of work to get it back." (p.56). Moreover, IMG's enter the second phase of personal and professional disorientation while undergoing their first months of training. They do not know how to behave with their peers and staff supervisors. They also are confused about their expected roles, their location within the medical hierarchy and about their areas of practice (Wong \& Lohfeld, 2008). Finally, IMG's enter the phase of adaptation, which they describe it as time consuming and demanding. For instance, they have to come up with strategies to adapt to the new situations. These strategies include keeping optimism, staying out of problems and trying to mix with their Canadians peers (Wong \& Lohfeld, 2008).

Foster's research paper entitled "Foreign Trained Doctors in Canada: Cultural Contingency and Cultural Democracy in the Medical Profession" examines the differential relationship between 
IMG's and the Canadian medical system as a way of explaining the devaluation of credentials. In fact, the medical profession is an element of a cultural-based power system that supports "White" male privilege and turns into the disadvantage of foreign-trained non-White and nonEuropean doctors (Foster, 2008). There are hidden rules and unconscious procedures that reinforce "Whiteness" through controlling the process of entry, treatment, recruitment and promotion of non-White and non-Europeans in the Canadian society (Foster, 2008).This is very problematic, because based on these rules every international medical graduate who does not fit into the imposed norms associated with whiteness in Canada is socially constructed as "other". It is therefore appalling to discover that IMG's face institutional exclusion and become subjects to those hidden rules simply because of their country of origin and racial otherness. The government remains limited to support the current system controlled by self -regulatory bodies, but it ignores the calls for more comprehensiveness and accessibility for foreign-trained physicians to the medical professions (Foster, 2008). Most of international medical graduates (IMG's) fail to obtain jurisdictional licenses to practice in Canada. These reasons are numerous such as the consideration of lack of knowledge and skills, required preparation and the limited access to assessments and trainings necessary to be employable in Canada (Foster, 2008). The Medical Council of Canada and other provincial medical authorities require IMG's to comply with cultural competency norms that are specific on how the medical profession is practiced in Canada. The Canadian cultural competency norms are the perspectives, values, beliefs and characteristics of privileged mainstream elite in the society. The "White privilege" and dominance are reproduced through discriminatory hiring practices, using the competency norms to racialize the skills and knowledge of highly skilled immigrants (Shibao, 2015). Under the same norms, all the individuals who are non-White are considered as less competent. Knowledge 
and practice are important competencies that allow growth and employment access in the Canadian society (Ehlers, 2013). Therefore, it is not simply true that non-White and nonEuropeans medical doctors are not competent because competency is not only measured by a language or a culture but by acquired knowledge. The same self-regulatory bodies use credentialism and licensing procedures such as writing numerous and complex examinations as a way of cultural exclusion of foreign-trained physicians and trivialization of their skills in regards to their contribution to the Canadian society (Foster, 2008). Although, most of the information is accessible online, most of IMG's also face the lack of support from Canadian agencies to understand the licensure procedures (Foster, 2008). IMG's, who lack the financial resources necessary to complete the licensing, found the certification process long and costly. Moreover, IMG's consider the training and assessments required by the Canadian professional organization as duplicate (Foster, 2008). Most of IMG's do not believe that they lack skills or competency to practice medicine in Canada but they suffer from the misperception and the treatment of professional bodies while assessing their credentials using culturally biased procedures (Foster 2008). In the next section I will review literature on internationally-trained engineers.

\section{Internationally-trained Engineers}

Girard and Bauder (2007) explain the licensing procedure in Canada for foreign-trained engineers. This process did not change over the years and the licensing requirements remain the same today. In order to practice engineering in Ontario candidates must satisfy various

requirements. First, they have to be Canadian citizens or permanent residents of Canada. Second, they have to hold a bachelor degree in engineering from a Canadian university program accredited by the Canadian Council of Professional Engineers and the Canadian Engineering Accreditation Board or equivalent. Foreign-trained engineers in Ontario are assessed by 
Professional Engineering Ontario (PEO) through interviews and examinations against the Canadian standards. Third, candidates must have four years of work experience in engineering, including one year of Canadian experience under the supervision of a Canadian licensed engineer. Fourth, applicants must pass the PEO's Professional Practice Exam (PPE) that tests professional practice, candidates' knowledge and application of ethics and engineering law and liability. Finally, applicants must be of good character and reputation as well as proficient in English (Girard \& Bauder, 2007). Similarly to the certification process of medical doctors, this process is complicated and time consuming. The use of expressions such as must be of a good character and reputation is controversial because it gives a prejudice about foreign-trained engineers' personalities.

Various studies examined the position of foreign-trained engineers in the Canadian labour market and findings reveal that most of foreign-trained engineers are not able to gain access to licenses to practice engineering in Canada (Girard \& Bauder, 2007). Non-licensed engineers are allowed to practice, if they are supervised by a Canadian licensed engineer. Foreign-trained engineers that are not able to pass the certification, become subordinate to Canadian engineers that obtain certification through an easier process (Bauder, 2003). Girard and Bauder (2007) affirmed that "foreign engineers without Canadian work experience could be characterized as unqualified and the work they performed as a potential threat to public safety". Regulators use this bureaucracy to protect the public interest and to make sure that individuals practicing engineering are fully qualified (Girard \& Bauder, 2007). This kind of practice is completely incoherent because engineering safety norms are universal and do not need a Canadian experience. 
George and Chaze's (2014) report on the findings of international engineers' experiences through interviewing 20 participants: 15 males and 5 females from 11 different countries located in Asia, Middle East and Latin America. The majority of participants believe that the intersection of English language skills, religion, ethnicity and foreign education contributed to their exclusion from practicing their profession in Canada (George \& Chaze, 2014). Internationally-trained engineers experienced discrimination in the process of credential assessment and finding an employment in Canada (George \& Chaze, 2014). Professional organizations and other institutions place race, language, ethnicity and religion, along with the outsider status of foreigntrained engineers as identity markers and use it against them (George \& Chaze, 2014). International candidates must internalize the habitus of the engineering profession within the Canadian norms instead of the universal scientific principles of engineering (Girard \& Bauder, 2007. This means they have to know the practices associated with communication and presentation skills, work place behaviour, personal ethics and dress code (Girard \& Bauder, 2007). In short, internationally-trained engineers are excluded from the labour market by professional organizations based on their cultural practices and lack of cultural capital, unless they demonstrate their adherence to the Canadian norms. Also, since engineering is universal there is no concrete proof that the Canadian norms are necessary to practice the profession of engineering in Canada. For a better preparation for certification, professional organizations suggest internationally-trained engineers to undergo bridging programs.

Professional Organizations support bridging programs because they help highly skilled immigrants to prepare for the licensing exam that is required to practice their profession (George $\&$ Chaze, 2011). Bridging programs are training and license preparation programs that fill in the gap between the educational and work experience of the highly skilled immigrants that come to 
Canada (George \& Chaze, 2011). Most of the foreign-trained engineers that enroll in bridging programs affirmed that they are short, generic and the programs do not help immigrants to pass the licensing exam (George \& Chaze, 2011). In order to participate in the bridging programs, foreign-trained engineers must have their credentials positively assessed. In case of the lack of financial resources to pay for the credential assessment service, international engineers cannot obtain an equivalency, which prevents them from enrolling into bridging programs (George and Chaze, 2011).

\section{Methodology}

\section{Research Problem}

Professional organizations such as Canadian Medical Association and Engineers Canada play a significant role in excluding highly skilled immigrants from gaining professional positions in the Canadian labour market. Existing literature underlines the non-recognition of foreign education and work experiences of highly skilled immigrants, but it fails to explain the discrepancy between immigration selection policy and practices of professional organizations towards them. The purpose of this research is to identify the gap in existing research about the functioning of such organizations and its impact on highly skilled immigrants.

\section{Research Questions}

Why do professional organizations such as Canadian Medical Association and Engineers Canada create barriers for highly skilled foreign doctors and engineers to practice their own profession in Canada? How do these practices exclude?

\section{Context, purpose and significance of the study}

Political economy framework explains the context in which highly skilled immigrants particularly medical doctors and foreign-trained engineers are selected to come to Canada. My 
research will underline the gap that exists between immigration policy of selecting highly skilled immigrants and the barriers made by professional organizations to exclude them from practicing their professions. My research will incite the professional organizations to review their credential assessment process and the certification process (even if it is a slight adjustment) to allow more skilled immigrants to practice their professions in Canada. The Canadian government can enforce more pressure and regulations on professional organizations and employers. For instance, policies that can ensure that the credentials are assessed using new criteria, and that the certification process becomes less complicated for highly skilled immigrants.

\section{Scope- limitations}

This research does not address other professions that are not regulated by professional organizations (i.e. management positions in banking and finance), it only focuses on how professional organizations operate in Canada. One limitation to my study is that it only covers the certification process of two regulated professions among many others such as nursing, law, architects and so on. The results of this study cannot reflect on the functioning of other regulated professions as they might have different certification process. Another limitation of this research is the huge amount of data available in the professional organizations' websites. The analysis only covers a part of data which increases the possibility to miss important information that can strengthen this study.

\section{Researcher Location and Reflexivity}

Reflexivity is a major strategy for the quality control in a research. My personal experience and my willingness to improve highly skilled immigrants' situation in the Canadian labour market make this study significant. Although my path is different, I studied engineering abroad and I share many of the lived experiences of other foreign-trained engineers, such as 
credential and previous work experience devaluation and lack of Canadian experience. My position in this research gives me a head start and better knowledge about the barriers and issues that highly skilled immigrants deal with after they arrive to Canada.

\section{Approach and Strategies}

This research uses a qualitative critical discourse analysis to analyze data. Qualitative methods are well suited to uncovering processes of exclusion that are hidden in everyday institutional practices. Conversely, quantitative methods seek explanation and causation based on empirical values (Collingridge, et al. 2008). Qualitative research allows review of literature and data on the surface and in-depth to provide a better understanding of how professional organizations exclude highly skilled immigrants from practicing their professions. In particular, I use a Foucauldian critical discourse analysis in order to examine the relationship between knowledge and power as part of social and institutional practices (Hodges, et al. 2008). This approach is complementary to the Bourdieusian approach that I used in the literature review. In fact, Bourdieu's analysis affirms that the institutionalization of cultural capital leads to the reproduction of the existing colonial structure, while the Foucauldian approach examines the mechanisms of this colonial structure in the society. Critical discourse analysis is used in this research to closely examine patterns in the organization texts as reported on organization's websites. This serves to deconstruct the hidden power that professional organizations apply to prevent foreign-trained medical doctors and engineers from practicing their professions in Canada. The analysis also addresses the question: How do discourses support institutions (professional organizations) and reproduce power relations? 


\section{Data Collection}

Data has been collected from websites of federal professional organizations such as Canadian Medical Council of Canada (MCC) and Engineers Canada (EC). Data has also been retrieved from the provincial professional organizations such as The College of Physicians and Surgeons of Ontario (CPSO), Professional Engineers of Ontario (PEO) and Association of Professional Engineers and Geoscientists of British Columbia (APEGBC). The objective was to collect information that explained how professional organizations exclude highly skilled immigrants from practicing their professions in Canada.

\section{Data Analysis}

I used a SWOT analysis as part of my critical discourse analysis of data from professional organizations' websites particularly the websites related to the process of certification and the requirements for certification. SWOT is a method that uses the internal and external environment of the organization analysis or a structural or procedural components analysis to establish the main strengths, weaknesses, opportunities and threats (Verboncu \& Condurache, 2016). The use of SWOT analysis is very important since it allows for the evaluation of: 1) strengths that are fundamental resources contributing to professional organizations success; 2) weaknesses that are lack of resources or capabilities in the functioning of professional organizations; 3) opportunities that are external recommendations to improve the functioning of professional organizations and, 4) threats that are external risks threatening the functioning of professional organizations (Simmering, 2006). A series of questions can be asked to go through the process of critical discourse analysis: What are the facts in the text? What kind of categories and activities are found? Who gains (or looses) from that particular subject position? What are the rules that are imposed? How do they sound plausible? Why is it written 
that way? Is it common sense? The critical discourse analysis will illustrate the nature of roles and relationships between international medical graduates IMG's / foreign-trained engineers and the professional organizations (Hodges, et al. 2008). Such analysis can be used to rethink or reconfigure those roles that have evolved with time. Consistent with the political economy perspective that informed this study's literature review, the SWOT and discourse analysis seek to uncover power inequalities and the links between dominant discourses and broader political and economic structures.

\section{Dissemination of Results/Findings}

The audience of for this paper ranges from policy makers to professional organizations that control the higher segment of the labour market as well as Canadian employers, academic colleagues and professors. It is important that policy makers continue working on policies in order to improve labour market outcomes for highly skilled immigrants such as international medical graduates IMG's and foreign-trained engineers. The goal of this research is to put pressure on the professional organizations in order to make the requirements of regulated professions suitable to highly skilled immigrants and to make an easier certification process. My paper also contributes to important discussions about discrepancies between the immigration policy and the exclusionary practices of professional organizations towards highly skilled immigrants.

\section{Analysis}

\section{Critical Discourse Analysis of professional organizations}

Critical discourse analysis provides an account of the role of language, use of language and the dominant discourse that describes the production of dominance and inequality (Mogashoa, 2014). In order to perform a critical discourse analysis of the functioning of 
professional organizations in Canada, I offer the following SWOT analysis that evaluates the certification process of the professions of medical doctors and engineers in the federal and provincial level.

\section{Medical Doctors ${ }^{1}$}

\section{Strengths}

The fundamental strength of the Medical Canada Council and the College of Physicians and Surgeons of Ontario is the well structured data about the certification process. Steps for certification are explained in detail and are accessible to all online users. The following paragraph is retrieved from the Medical Canada Council website where the certification process is explained:

Physicians applying for the first time to become licensed to practise medicine in a Canadian jurisdiction may achieve full licensure only if they:

1. Have a medical degree from a medical school that, at the time the candidate completed the program, was listed in the World Directory of Medical Schools. Please see our latest news post regarding IMED and WDMS for more information, or a Doctor of Osteopathic Medicine degree from a school in the United States accredited by the American Osteopathic Association Commission on Osteopathic College Accreditation; and

2. Are a Licentiate of the Medical Council of Canada; and

3. Have satisfactorily completed a discipline-appropriate postgraduate training program in allopathic medicine and an evaluation by a recognized authority; and

4. Have achieved certification from the College of Family Physicians of Canada or the Royal College of Physicians and Surgeons of Canada or the Collège des médecins du Québec.

The web-based platform Physicians.ca is an efficient tool for International Medical Graduate because it allows them to search for all information they need before coming to Canada including self-assessment tests, exams and applications to obtain certification.

\footnotetext{
${ }^{1}$ Appendix Table 1 and Table 2
} 


\section{Weaknesses}

The main weakness of the functioning of such organizations is the complex certification process, which is required for International Medical Graduates. Many entities are involved in these processes, such as Medical Canada Council and the federal and provincial regulatory colleges. This creates confusion for IMG's because they have no idea with whom they are dealing with throughout the multistage process. Federal and provincial regulations agree that the license provided by the Medical Canada Council (Series of examinations before and after coming to Canada) is one part of the certification process. IMG's still need to successfully complete a discipline-appropriate post secondary degree (Residency) to finally obtain the practicing certificate from the College of Family Physicians after fulfilling all the requirements. There is a hidden power inequality practiced by these organizations since they use provincial and federal regulations as a way to legitimate the requirements opposed on IMG's according to the Canadian Standards.

The path of certification is another weakness because of the amount of time and money that is required. This process can take from two to six years and there is no guarantee for IMG's to obtain the certificate, even with paying a minimum of $\$ 1700$ for each examination. Prior to arriving to Canada the process includes the Confirmation of medical degree and undergraduate degree obtained outside of Canada and US, online self-assessment exam, submission of credentials through MCC Physician Credentials Repository, and taking the Medical Council of Canada Evaluating Examination (MCCEE). There is a World repository that allows IMG's to confirm if their Medical school and its degree are recognized in Canada. Regardless of the evaluation made by the Medical Council of Canada Physician Credentials, IMG's are asked to take the Medical Council of Canada Evaluating Exam (MCCEE) that consists of 4 hours 
computer exams assessing IMG's basic medical knowledge and readiness to enter their first year of supervised postgraduate training in Canada. Many questions focus on general practice and include 180 multiple-choice questions (with topics relating to medical knowledge about pediatric health, maternal health, adult health, mental health and population health and ethics). This exam is the concrete proof that these professional organizations downgrade the competencies and academic credentials of IMG's.

After their arrival to Canada, IMG's that passed the MCCEE exam need to take two more examinations, the first one is the National Assessment Collaboration NAC and the second one is the Medical Council of Canada Qualification MCCQE, which includes part I and II. The NAC is one day exam that tests IMG's readiness to enter to a residency training program, but passing this exam does not guarantee a residency position. Such a rule prevents many IMG's from completing the certification process because finding a residency spot is one of the core requirements to get a certification in Canada. The MCCQE with its two parts is a three days computer based exam and class examination that assesses the knowledge, clinical skills and attitudes of the IMG's before starting the practice of medicine in Canada. These exams are complex and are limited only to 4 times within 3 years, which further reduces the chance of IMG's to get their certification done. Also, IMG's cannot write the part II of the MCCQE without post secondary residency training. All these elements represent a clear way of selection and elimination of more IMG's.

\section{Opportunities}

International medical graduates require more support from the medical organizations and government in order to facilitate their integration into Canada (Walsh et al, 2011).The nonrecognition of international credentials remains critical for IMG's because it prevents them from 
practicing medicine in Canada. It is important to notice the efforts made by Ontario in 2006 through passing fair access legislation that asks regulators to use transparent, fair, impartial and objective practices in their registration processes but thin (Augustine, 2015). However, there are many ways to improve the process of certification and increase the spots of certified IMG's. First, there is a need to create a database that links the process of immigration and the certification process of IMG's. Once IMG's apply for immigration, they are informed through this data base about the certification process and the necessary steps to take in order to save time. Second, the credentials assessment process needs to be reviewed as it is currently time consuming and not efficient. There are many barriers that delay the credential assessment of IMG's, such as the requirement of transcripts and academic records to be sent from the medical school directly. Most of IMG's do not have control over this administrative task that the medical school has and this can prevent their credentials from being assessed. Third, the National Assessment Collaboration and the Canadian Resident matching service should be replaced by bridging programs that allow IMG's to access to residency programs once completed. Fourth, the cost and time of the certification process need to be decreased. A way of doing this is to reduce the MCCQE examination to one part and lower its price.

\section{Threats}

Due to the complex and unguaranteed certification process of IMG's, Canada risks having an ongoing medical doctors' shortage particularly in under-served regions of Canada. Another threat that these organizations face, is losing the quality and competency of IMG's due to non-practicing for a long time. This could be the case for specialists and surgeons that have been practicing for years. Finally, due to the increased number of IMG's with no certification, 
the federal and provincial governments may put more pressure on professional organizations to review their certification procedures.

\section{Engineers $^{2}$}

\section{Strengths}

The analysis of Canada Engineers, Professional Engineers Ontario and Professional Engineers and Geoscientists of British Columbia's certification process reveals a few strengths. First, all the bodies have detailed information about the certification process that is accessible online. Some provinces have self-assessment tools that help foreign-trained engineers evaluate their cases and obtain necessary information for the certification path. Second, foreign-trained engineers have access to alternatives to some parts of the certification process. For instance, if they fulfill specifics requirements, such as being exempted from some academic examinations if their work experience is more than 5 years. Foreign-trained engineers can also obtain a shortcut to certification process by entering bridging program (Engineering Intern EIT) if they are in Canada less than six months by the time they apply for it. Finally, they can benefit from the validation of up to twelve months of work experience obtained during undergraduate studies.

\section{Weaknesses}

There are numerous weaknesses of the professional organizations that regulate engineering in Canada. The process of certification is time and money consuming as it takes from three to six years, costing a minimum of $\$ 1644$ per exam per individual. The certification process starts with the submission of an application and the credentials evaluation before coming to Canada. Even if the evaluation of the credentials reveals that they are almost similar to the Canadian standards, foreign-trained engineers are still assigned with technical exams to prove

\footnotetext{
${ }^{2}$ Appendix Table 3, Table 4 and Table 5
} 
their knowledge. Similar to the medical regulatory bodies, engineering organizations put in place a complex licensing process for foreign-trained engineers. Once they arrive to Canada, many foreign-trained engineers have to translate their documents and academic records into either English or French and submit them to continue the certification process. This involves unnecessary financial costs and time that delays the process. When foreign trained engineers are asked to meet the work experience requirements (four years including one in Canada), be of a good character, have their language assessed and complete the Professional Practice Examination (to meet the Canadian professional and ethical standards). It is only after completing these entire steps that foreign- trained engineers can finally apply for certification that is given by provincial organizations.

Most of provinces use the Professional Engineer Act (that ensures the protection of Canadian public interest) to legitimize the strict requirements that they impose on foreign-trained engineers. There are many barriers that prevent foreign trained engineers from obtaining their certification. They have to go through complex examinations to meet the academic and language requirements; they are controversially asked to demonstrate their character in terms of trustworthiness, respect, responsibility, fairness, good citizenship and caring in order to meet the criteria of good character. Furthermore, they have to prove the use of their engineering experience, and finally, they have a limited time to pass the Professional Practice examination that tests them on how should engineering be practiced in Canada. All these factors show that there are many barriers facing foreign trained engineers. These barriers are often hidden under engineering regulations. 


\section{Opportunities}

Provincial engineering regulators are currently working together in a national project to improve the licensing process of foreign-trained engineers. Regulators aim to tackle the issue of limited access to the Canadian work experience and the competencies related to local knowledge of engineering practice in Canada (Augustine, 2015). Canadian employers hesitate to hire foreign- skilled engineers because they consider their communication, interpersonal and academic skills to be different than the Canadian born engineers (Friesen \& Ingram 2013). However, there are other barriers in the licensing process that should be considered. There is a need to create a database that links the process of immigration and the certification process of foreign-trained engineers. Once they apply for immigration, foreign-trained engineers can be informed through this database about the certification process and the necessary steps in order to save time. In order to improve the process of certification for foreign-trained engineers, professional organizations could eliminate extra examinations related to the academic requirements. There should be a fair system that evaluates the foreign-trained engineers' credentials and facilitate their certification process. Therefore, I suggest only one examination to meet the academic requirement, instead of three exams. Finally, there should be a simpler version of the Professional Practice Examination because once foreign-trained engineers are employed in Canada they will become familiar with the professional and ethics standards of Canadian engineering.

\section{Threats}

Due to the complexity of the certification process of engineering, professional organizations risk losing some competent foreign-trained engineers who may choose to change their careers. There is also a risk of governments putting pressure on professional organizations 
to review their certification process. Finally, some engineers will choose to move from a province to another if they find the practice in a province easier than another. For example, only in British Columbia, foreign-trained engineers may go through an interview as an alternative to the requirement on engineering work experience if it was obtained under a different discipline from the acquired academic degree.

\section{Dominant Discourse}

Professional organizations occupy the position of the writer / speaker and they use specialist social language that is tailored to a specific audience (Mogashoa, 2014). They design their texts according to their position and they deliver a message to professional immigrants such as international medical doctors and foreign trained engineers. Readers of this content will then situate themselves and can respond based on how they situate in the text (Mogashoa, 2014). The professional organizations take the position of the leader because they create a procedure (certification process) for others to follow and to comply with. The relationship between professional organizations and highly skilled immigrants is not only limited to steps to follow. The analysis of professional organizations' websites reveals that they purposely use expressions such as:

- Applicants must demonstrate good character

- You must fulfill all the requirements

- This tests your knowledge of laws and professional standards you will be held accountable

- You must demonstrate an ability

- To take responsibility for your work in Canada 
- This is to demonstrate that you can communicate clearly and professionally with colleagues, clients and the public verbally and in writing

There is a hidden discourse that reproduces the power inequality of a dominant lobby of institutions over an obedient audience that has no choice but to obey. As Mogashoa (2014) elucidates, the words of those in power are taken as "self- evident truths" and the words of those not in power are dismissed as irrelevant, inappropriate or without substance (p.105).

\section{Discussion}

\section{International Medical Graduates}

The findings of this discourse analysis confirm that the certification process established by the Canadian professional organizations protects dominant Canadian beliefs and norms, and as a result the policies construct the foreign-trained professional as being the "other" who is subordinate to recognized Canadian professionals. They use federal and provincial regulations such as Medicine Act 1991 power tool to justify the tough requirements imposed on international medical graduates. Procedures are written in an authoritarian style to confirm the superiority of Canadian norms over immigrants' identities and knowledge. The devaluation of credentials remains the most important tool that these organizations use to practice their supremacy on international medical graduates. Shibao (2015) noted that the demand for Canadian credentials or experience by the professional organizations hide the more overt references for race and ethnicity of highly skilled immigrants. My analysis reveals that the certification process penalizes IMG's because they are required to pass all the examinations even if they have been practicing medicine for years. These findings align with Shibao's (2009) argument that highly skilled immigrants' credentials are trivialized and considered incompatible with the Canadian standards. 
Curtis and Dube (2015) highlight the struggle of IMG's to secure residency spots, according to their research only around $10 \%$ of IMG's that applied in 2003 were able to get residency training and since then the number of successful applicants has not significantly increased. The analysis of my research confirms the difficulty of getting residency spots as the NAC examination serves only to get IMGs familiar with the Canadian residency system; however, the exam does not guarantee access to the required post-secondary training. As a result, fewer IMG's are certified and able to practice in Canada. The certification process is therefore, a system full of traps, once the individual escapes from one he finds himself stuck in another and it can take years to get out of these traps.

\section{Foreign-trained Engineers}

The findings of the critical discourse analysis show that the engineering certification process relies on Professional Engineers Act that protects and serves the public interests to impose complex requirements on foreign-trained engineers. These barriers prevent them from practicing in Canada. This ties to Girard and Bauder (2007) argument that those regulations are used to block the so called "Threat" of foreign-trained engineers to the domestic engineers. The analysis of my research reveals that foreign-trained engineers are asked to evaluate their work experience and explain how it can benefit the Canadian market. This confirms that most of foreign-trained engineers struggle to obtain Canadian experience based on their ethnicity, language and educational knowledge (George \& Chaze, 2011). Foreign-trained engineers need to accumulate cultural capital in Canada to overcome their economic disadvantage (Shan, 2013). However, professional organizations do not facilitate their integration in the Canadian labour market. 
The process of certification for foreign-trained engineers looks slightly easier than IMG's, but obtaining the certification can take from three to six years. Similar to the international medical doctors, foreign-trained engineers suffer from the non-recognition of their credentials (Augustine, 2015). Professional organizations have the exclusive institutional power to assess the credentials and to determine if foreign-trained professionals are comparable with the Canadian standards. This is evident in the fact that foreign-trained engineers must prove their academic knowledge through a series of examinations. According to Shibao (2015), this practice shows how Canadian institutions treat the competencies of foreign-trained engineers as being inferior and subordinate. As an alternative to bypassing those academic examinations, professional organizations offer bridging program, such as Engineer Intern program, but they are accessible only to foreign-trained engineers, who have been in the country less than six months.

Finally, the analysis shows that professional organizations require foreign-trained engineers to be of a good character and pass the Professional Practice Examination to ensure they know how engineering is practiced in Canada. These two requirements are problematic because, on the one hand, engineering is universal and, on the other hand, asking foreign-trained for values of trustworthiness and honesty means that they under-value their character. There is an assumption that the Canadian values and practices are superior to the foreign ones and this is used by the professional organizations against foreign-trained engineers.

\section{Conclusion}

Global capitalism and neoliberalism forces Canada to need highly skilled immigrants such as international medical graduates and foreign-trained engineers. On one hand, they are selected to come to Canada based on their high education level and professional experiences on the other hand, the Canadian government allows professional organizations to dictate the 
exclusionary rules of practicing professions, such as medicine and engineering. These organizational rules prevent IMG's and foreign-trained engineers from practicing in Canada. The critical discourse analysis that I conducted in this research asserts that there are systemic power inequalities hidden in the bureaucratic practices of professional organizations towards IMG's and foreign-trained engineers. These inequalities are highly supported by profession regulations that protect dominant Canadian values and perceive immigrants as inferior and incompetent regardless of their previous educations and work experiences.

IMG's and foreign-trained engineers go through a complex path of certification full of challenging due to the non-recognition of their credentials and work experiences. The consequences are evident since very few individuals complete the certification process and therefore most of them are unable to practice their professions in Canada (Augustine, 2015). The analysis of this study shows that there are many ways to improve the certification process and allow more IMG's and foreign-trained engineers to obtain their certifications. For instance, this process can be efficient if they reduce the time of the certification by eliminating unnecessary examinations and make the prices affordable for IMG's. Also, professional organizations have to fix the issues of credential assessments and limited spots for post-secondary training (residency). Bridging programs can be good alternatives only if they give the possibility to secure a residency spot after their completion. For the foreign-trained engineers, there is also a need to provide fair credentials assessment and eliminate unnecessary examinations to accelerate the certification process. The government of Canada and policy makers are in the position to link the immigration process with the certification process and provide efficient solutions to resolve this discrepancy. As Canada becomes more reliant on immigration to improve the economic sector, professional 
organizations should review their requirements more than ever to allow more practicing foreigntrained Engineers on board (Augustine, 2015). 


\section{Appendix}

Table 1: SWOT Analysis Medical Certification Process (Medical Canada Council and Physicians.ca)

\begin{tabular}{|c|c|}
\hline $\begin{array}{l}\text { Strengths } \\
\text { - Well structured certification process } \\
\text { - Clear definition of International Medical } \\
\text { - Graduate } \\
\text { - Online-based application process } \\
\text { - Accessibility to the tests and exams online }\end{array}$ & 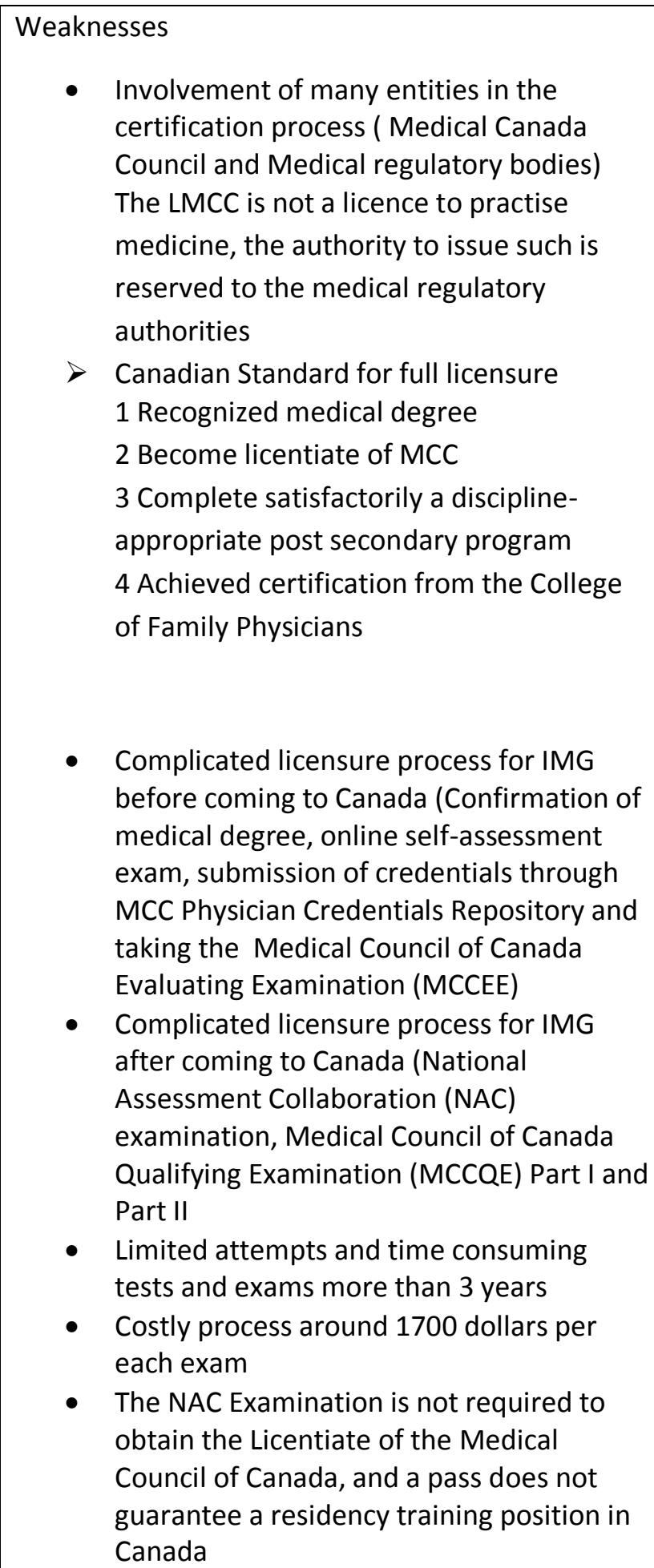 \\
\hline
\end{tabular}


Opportunities

- Develop a connection between professional organizations and the immigration process for IMG's

- Improve the credential assessment process

- Provide IMG's with simple information regarding regulations of practicing medicine in Canada

- Shorten the time of the certification process by including more in the preimmigration process

- Eliminate the NAC exam and allow bridges programs to provide an opportunity for residency instead of the Canadian Resident matching service

- Lower the cost of exams and tests
Threats

- Continuous medical doctors shortage due to complicated licensing process

- Losing the quality and competency of experienced surgeons and doctors due to stoppage in practicing

- Pressure from federal and provincial government to review the certification procedures 
Table 2: SWOT Analysis Medical Certification Process (The college of Physicians and Surgeons of Ontario)

\begin{tabular}{|c|c|}
\hline $\begin{array}{l}\text { Strengths } \\
\text { - Detailed explanation of the certification } \\
\text { process } \\
\text { - Online-based application process } \\
\text { - Accessibility to the tests and exams online }\end{array}$ & $\begin{array}{l}\text { Weaknesses } \\
\text { - Use of complex Ontario Regulation } \\
\text { Medicine Act } 1991 \text { to impose strict } \\
\text { requirements for certification delivery } \\
\text { - Involvement of many entities in the } \\
\text { certification process ( Medical Canada } \\
\text { Council and Medical regulatory bodies) } \\
\text { The LMCC is not a licence to practise } \\
\text { medicine, the authority to issue such is } \\
\text { reserved to the medical regulatory } \\
\text { authorities } \\
\text { Canadian Standard for full licensure } \\
\text { 1 Recognized medical degree } \\
2 \text { Become licentiate of MCC } \\
\text { 3 Complete satisfactorily a discipline- } \\
\text { appropriate post secondary program } \\
4 \text { Achieved certification from the College } \\
\text { of Family Physicians } \\
\text { Requirement of post secondary training } \\
\text { (Residency program) } 2 \text { years for family } \\
\text { medicine and } 4 \text { to } 5 \text { years for medical } \\
\text { specialists } \\
\text { Costly process }\end{array}$ \\
\hline $\begin{array}{l}\text { Opportunities } \\
\text { - Develop a connection between } \\
\text { professional organizations and the } \\
\text { immigration process for IMG's } \\
\text { - Improve the credential assessment } \\
\text { process } \\
\text { - Shorten the time of the certification } \\
\text { process by including more in the pre- } \\
\text { immigration process } \\
\text { - Eliminate the NAC exam and allow bridges } \\
\text { programs to provide an opportunity for } \\
\text { residency instead of the Canadian } \\
\text { Resident matching service } \\
\text { - Reduce the cost of exams and tests }\end{array}$ & $\begin{array}{l}\text { Threats } \\
\text { - } \quad \text { Continuous medical doctors shortage due } \\
\text { to complicated licensing process } \\
\text { - Losing the quality and competency of } \\
\text { experienced surgeons and doctors due to } \\
\text { stoppage in practicing } \\
\text { - } \begin{array}{l}\text { Pressure from federal and provincial } \\
\text { government to review the certification } \\
\text { procedures }\end{array}\end{array}$ \\
\hline
\end{tabular}




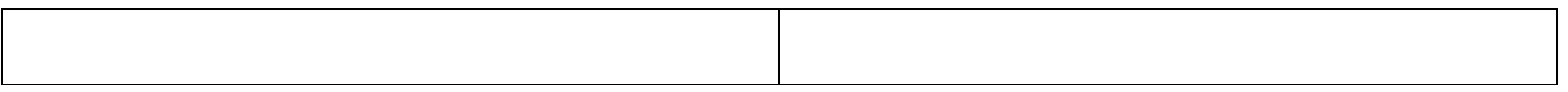

Table 3: SWOT Analysis International Engineering Certification Process (Engineers Canada)

\begin{tabular}{|c|c|}
\hline $\begin{array}{l}\text { Strengths } \\
\text { - Detailed explanation of the certification } \\
\text { - } \text { process } \\
\text { - Accen guidance for alternatives } \\
\end{array}$ & $\begin{array}{l}\text { Weaknesses } \\
\text { - } \quad \text { Time consuming process } 3 \text { to } 6 \text { years } \\
\text { between the status of Engineer in Training } \\
\text { and Professional Engineer (P.Eng) } \\
\text { - Costly process } \\
\text { - Complicated academic criteria made in a } \\
\text { way to push foreign-trained engineers to } \\
\text { complete additional courses and take } \\
\text { other examinations } \\
\text { - Complex evaluation of engineering work } \\
\text { experience (Demonstrating seven core } \\
\text { engineering competencies) } \\
\text { - Requirement to be of a good character } \\
\text { (Controversial definition of a good } \\
\text { character) } \\
\text { Requirement of passing Professional } \\
\text { Practice examination to meet professional } \\
\text { and ethical standards in Canada }\end{array}$ \\
\hline $\begin{array}{l}\text { Opportunities } \\
\begin{array}{l}\text { - } \\
\text { Facilitate the obtaining of the Canadian } \\
\text { experience } \\
\text { Make one category of additional } \\
\text { examination instead of three categories } \\
\text { - } \text { Eliminate the requirement being of a good } \\
\text { character } \\
\text { Simple version of Professional Practice } \\
\text { examination for foreign-trained engineers }\end{array}\end{array}$ & $\begin{array}{l}\text { Threats } \\
\text { - Risk of losing the quality and competency } \\
\text { of experienced engineers due to long } \\
\text { certification process } \\
\text { - } \begin{array}{l}\text { Pressure from federal and provincial } \\
\text { government to review the certification } \\
\text { process }\end{array}\end{array}$ \\
\hline
\end{tabular}


Table 4: SWOT Analysis Professional Engineers Ontario

\begin{tabular}{|c|c|}
\hline $\begin{array}{l}\text { Strengths } \\
\text { - Detailed explanation of the } \\
\text { certification process } \\
\text { - Open guidance for alternatives } \\
\text { - Possibility of going through an } \\
\text { interview if the work experience is } \\
\text { between } 5 \text { to } 10 \text { years } \\
\text { - } \text { Accessible online information } \\
\text { - Possibility of bridging program } \\
\text { - Engineering Intern EIT) } \\
\text { - } \text { gradunting up to } 12 \text { months of pre- } \\
\text { gradion experience }\end{array}$ & $\begin{array}{l}\text { Weaknesses } \\
\text { - Professional Engineers Ontario legitimates their } \\
\text { certification requirements by using the } \\
\text { Professional Engineer Act } \\
\text { - Time consuming process } 3 \text { to } 6 \text { years between the } \\
\text { status of Engineer in Training and Professional } \\
\text { Engineer (P.Eng) } \\
\text { - Costly process minimum } \$ 1644 \\
\text { - Requirement to resubmit translated documents } \\
\text { once foreign-trained engineers arrive to Ontario } \\
\text { - } \text { Foreign-trained engineers will still have to } \\
\text { complete technical exams whether their } \\
\text { credentials are recognized or not } \\
\text { Requirement to be of a good character } \\
\text { (Controversial definition of a good character) } \\
\text { Complex evaluation of engineering work } \\
\text { experience (Demonstrating five core engineering } \\
\text { competencies) } \\
\text { Requirement of passing Professional Practice } \\
\text { examination to meet professional and ethical } \\
\text { standards in Canada in limited time }\end{array}$ \\
\hline Opportunities & Threats \\
\hline $\begin{array}{l}\text { - Facilitate the obtaining of the } \\
\text { Canadian experience } \\
\text { - Make one category of additional } \\
\text { examination instead of three } \\
\text { categories } \\
\text { - Eliminate the requirement being of } \\
\text { a good character } \\
\text { - Simple version of Professional } \\
\text { Practice examination for foreign- } \\
\text { trained engineers }\end{array}$ & $\begin{array}{l}\text { - Risk of losing the quality and competency of } \\
\text { experienced engineers due to long certification } \\
\text { process } \\
\text { - Risk of foreign-trained engineers going to other } \\
\text { provinces }\end{array}$ \\
\hline
\end{tabular}


Table 5: SWOT Analysis Professional Engineers and Geoscientists of British Colombia

\begin{tabular}{|c|c|}
\hline Strengths & Weaknesses \\
\hline $\begin{array}{l}\text { - Self assessment tool to see if applicants } \\
\text { meet requirements } \\
\text { - } \text { Detailed explanation of the certification } \\
\text { - Possibility of going through an interview if } \\
\text { the work experience is between } 5 \text { to } 10 \\
\text { years } \\
\text { - } \text { Accessible online information } \\
\text { - Possibility of bridging program } \\
\text { - } \text { Cngineering Intern EIT) } \\
\text { - } \text { gradunting up to } 12 \text { months of pre- } \\
\text { Flexibility of going through an interview if } \\
\text { work experience is under a different } \\
\text { discipline from academic degree obtained }\end{array}$ & $\begin{array}{l}\text { - Time consuming process } 3 \text { to } 6 \text { years } \\
\text { between the status of Engineer in Training } \\
\text { and Professional Engineer (P.Eng) } \\
\text { - } \quad \text { Costly process minimum } \$ 2100 \\
\text { - Foreign-trained engineers will still have to } \\
\text { complete technical exams whether their } \\
\text { credentials are recognized or not } \\
\text { - Requirement to be of a good character } \\
\text { (Controversial definition of a good } \\
\text { character) } \\
\text { - Requirement of passing Professional } \\
\text { Practice examination to meet professional } \\
\text { and ethical standards in Canada in limited } \\
\text { time }\end{array}$ \\
\hline $\begin{array}{l}\text { - Facilitate the obtaining of the Canadian } \\
\text { experience } \\
\text { - Make one category of additional } \\
\text { examination instead of three categories } \\
\text { - Eliminate the requirement being of a good } \\
\text { character } \\
\text { - Simple version of Professional Practice } \\
\text { examination for foreign-trained engineers }\end{array}$ & \begin{tabular}{|l} 
Threats \\
- Risk of losing the quality and competency \\
of experienced engineers due to long \\
certification process \\
- Risk of foreign-trained engineers going to \\
other provinces
\end{tabular} \\
\hline
\end{tabular}




\section{References}

Augustine, H. J. (2015). Immigrant Professionals and Alternative Routes to Licensing: Policy Implications for Regulators and Government. Canadian Public Policy, 41(1), 514-527. doi: $10.3138 /$ cpp.2014-022

Anton, A. (2010). The Political Economy of Race and Class in Canada's Caribbean Diaspora. American Review of Political Economy, 8(2), 54-86. https://search-proquestcom.ezproxy.lib.ryerson.ca/docview/912208852?pq-origsite=summon

Association of Professional Engineers and Geoscientists of British Columbia (APEGBC) (2017). Become a Member. Retrieved from https://www.egbc.ca/Become-a-Member

Bauder, H. (2003) "Brain Abuse", or the Devaluation of Immigrant Labour in Canada. Antipode, 36(4), 699-717. doi: 10.1046/j.1467-8330.2003.00346.x

Callon, E. (2016). Unbalanced Scales of Global Capitalism: Analyzing Temporary Foreign Worker Programs in Canada. Canadian Graduate Journal of Sociology and Criminology, 5(1), 32-43. https://search-proquestcom.ezproxy.lib.ryerson.ca/docview/1812277474?pq-origsite=summon

Collingridge, D. S. \& Gantt, E. E. (2008). The Quality of Qualitative Research. American Journal of Medical Quality, 23(5), 389-395. doi:10.1177/1062860608320646

Coulthard, G. S. (2007). Subjects of Empire: Indigenous Peoples and the 'Politics of Recognition' in Canada. Contemporary Political Theory, 6(1), 437-460. doi: 10.1057/palgrave.cpt.9300307

Curtis, L. J. \& Dube, A. (2015). Demographics, Debt, and Practice Intentions of Medical Residents Training in Canada. Canadian Public Policy, 41(1), 138-149. doi: 10.3138/cpp.2014-037 
Delacourt, S. Physicians Groups Accused of Delaying Foreign Doctors. The Star, Ottawa Bureau. (2009, December 01). Retrieved from https://www.thestar.com/life/health_wellness/2009/12/01/physicians_groups_accused_of _delaying_foreign_doctors.html

Ehlers, U. D. (2013). Open Learning Cultures: A Guide to Quality, Evaluation, and Assessment for Future Learning. Retrieved from http://www.springer.com/gp/book/9783642381737\#aboutBook

Engineers Canada (2017). Information for Internationally trained Engineers. Retrieved from https://engineerscanada.ca/become-an-engineer/for-internationally-trained-engineers

Foster, L. P. (2008). Foreign Trained Doctors in Canada: Cultural Contingency and Cultural Democracy in the Medical Profession. International Journal of Criminology and Sociological Theory, 1(1), 1-25. http://ijcst.journals.yorku.ca/index.php/article/view/16148/15047

Friesen, M \& Ingram, S. (2013). Advancing Intercultural Competency: Canadian Engineering Employers' Experiences with Immigrant Engineers. European Journal of Engineering Education, 38(2), 219-227. doi: 10.1080/03043797.2013.766677

Girard, R. \& Bauder, H. (2007). Assimilation and Exclusion of Foreign Trained Engineers in Canada: Inside a Professional Regulatory Organization. Antipode, 39(1), 35-53. doi: 10.1111/j.1467-8330.2007.00505.x

Girard, R. \& Bauder, H. (2007). The Making of an Arcane Infrastructure: Immigrant Practitioners and the Origins of Professional Engineering Regulation in Ontario. The Canadian Geographer, 51(2), 233-246. doi: 10.1111/j.1541-0064.2007.00176.x 
George, U. \& Chaze, F. (2012). Looking for Work but Nothing Seems to Work: The Job Search Strategies of Internationally Trained Engineers in Canada. Journal of International Migration and Integration, 13(3), 303-323. doi: 10.1007/s12134-011-0197-1

George, U. \& Chaze, F. (2013). The Interlocking Oppressions of Employment Related Discrimination for Internationally Trained engineers in Canada. Canadian Social Work Review, 30(2), 119-137. doi: 10.1111/j.1755-618X.1981.tb01234.x

Hodges, B. D., Kuper, A. \& Reeves. S. (2008). Discourse Analysis. Science Database, 337(3), 15. doi: 10.1136/bmj.a879

Medical Council Canada (2017). Examinations. Retrieved from http://mcc.ca/examinations/ Mogashoa, T. (2014). Understanding Critical Discourse Analysis in Qualitative Research. International Journal of Humanities Social Sciences and Education, 1(7), 104-113. https://www.arcjournals.org/pdfs/ijhsse/v1-i7/12.pdf

Neiterman, E. \& Bourgeault, I. L. (2012).Conceptualizing Professional Diaspora: International Medical Graduates in Canada. Journal of International Migration and Integration, 13(1), 39-57. Springer Link. Web. Feb. 2012.

Physiciansapply.ca (2017). Practicing in Canada. Retrieved from http://physiciansapply.ca/practising-in-canada/

Professional Engineers Ontario (2017). International Engineering Graduates. Retrieved from http://www.peo.on.ca/index.php?ci_id=2061\&la_id=1

Shan, H. (2013). Skill as a Relational Construct: Hiring Practices From the Standpoint of Chinese Immigrant Engineers in Canada. Work, Employment \& Society, 27(6), 915-931. doi $10.1177 / 0950017012474710$ 
Shibao, G. (2009). Difference, Deficiency, and Devaluation: Tracing the Roots of NonRecognition of Foreign Credentials for Immigrant Professionals in Canada. The Canadian Journal for the Study of Adult Education, 22(1), 37-52.

https://cjsae.library.dal.ca/index.php/cjsae/article/viewFile/1002/991

Shibao, G. (2015). The Colour of Skill: Contesting a Racialised Regime of Skill from the Experience of Recent Immigrants in Canada. Studies in Continuing Education, 37(3), 236-250. doi: 10.1080/0158037X.2015.1067766

Simmering, M. (2006). SWOT Analysis. Retrieved from Gale Virtual Reference Library, go.galegroup.com/ps/i.do?p=GVRL\&sw=w\&u=rpu_main\&v=2.1\&id=GALE\%7CCX34 46300254\&it=r\&asid=98f5ba569ccd5ef03837b1d143309b35

The College of Physicians and Surgeons of Ontario. International Medical Graduates. Retrieved from http://www.cpso.on.ca/Registering-to-Practise-Medicine-in-Ontario/InternationalMedical-Graduates

Verboncu, I. \& Condurache.A. (2016). Diagnostics vs. SWOT Analysis. Revista de Management Comparat International, 17(2), 114-122. http://rmci.ase.ro/no17vol2/03.pdf

Walsh, A., Banner, S., Schabort, I., Armson, H., Bowmer, M. I. \& Granata, B. (2011). International Medical Graduates- Current issues. Retrieved from: https://afmc.ca/pdfffmec/05_Walsh_IMG\%20Current\%20Issues.pdf

Wong, A. \& Lohfeld.L. (2008). Recertifying as a Doctor in Canada: International Medical Graduates and the Journey from Entry to Adaptation. Medical Education, 42(1), 53-60. 